\title{
Konstrukcja komunikacji w reklamach leków i suplementów diety
}

Reklama jest rodzajem tekstu, przekazu językowego i wizualnego, który charakteryzuje się specyficzną formą komunikacji. Można w niej znaleźć szereg rozwiązań z obszaru perswazji mających na celu wzmocnienie przekazu i odziaływania na odbiorców. Od psychologicznych technik wpływu społecznego, przez językowe argumenty retoryczne, aż do technik wizualnych i neuropsychologicznych. Dlaczego? Głównym i ostatecznym celem reklamy jest skłonienie odbiorcy do zakupu danego produktu, a najlepiej przekonanie go, aby pozostał wiernym, długoletnim klientem. Reklamy są rodzajem tekstów, które nie są przetwarzane w sposób racjonalny, nie są dokładnie analizowane, a odbiorcy nie zastanawiają się, dlaczego są skonstruowane tak, a nie inaczej. Dlatego środki perswazyjne odgrywają bardzo istotną rolę - mają bowiem wzbudzić przekonanie, że odbiorca sam doszedł do wniosku, iż reklamowany produkt jest dla niego najlepszy, a podjęte działanie racjonalne.

Segmentem, w którym użycie specyficznych konstrukcji komunikacyjnych jest szczególnie mocno widoczne, jest sektor farmaceutyczny. Analiza językowa oraz wizualna ponad 70 reklam telewizyjnych leków i suplementów diety umożliwiła wyodrębnienie dominujących konstruktów komunikacyjnych.

\section{Zdrowie i choroba w dyskursie}

Zdrowie jest wartością, którą Polacy wymieniają jako jedną z najważniejszych w życiu. Na przykład w przeprowadzonym w 2015 roku przez GUS Badaniu spójności 
społecznej ${ }^{1}$ aż $66 \%$ badanych zadeklarowało, że zdrowie jest dla nich najważniejszą wartością. Jednocześnie coraz częściej możemy zetknąć się w mediach z reklamami leków czy suplementów diety. Bazując na wytwarzanych i powielanych strategiach komunikacyjnych oraz specyficznej konstrukcji językowej, producenci próbują nas przekonać, że ich produkt jest cudownym środkiem, który bardzo szybko rozwiąże nasze problemy zdrowotne. Wydatki na reklamy leków oraz suplementów diety z roku na rok rosną. Według raportu firmy Deloitte z 2016 roku opracowanego we współpracy z DNB Bank Polska ${ }^{2}$ wydatki Polaków na leki rosły w ostatnich dziesięciu latach średnio o 4,4\% rocznie.

Jednym z najważniejszych czynników wzrostu sprzedaży medykamentów może być reklama. Od 2011 roku segment farmaceutyczny znajduje się w ścisłej czołówce reklamodawców i pod względem wydatków na promocję niezmiennie pozostaje na drugiej pozycji, ustępując tylko sektorowi żywności i napojów ${ }^{3}$. Z analizy domu mediowego Codemedia wynika, że w pierwszym kwartale 2017 roku branża farmaceutyczna przeznaczyła na promocję ponad 311 milionów zł, czyli o 10\% więcej niż rok temu. Niekwestionowanym liderem wydatków na reklamę w tym sektorze jest Aflofarm ${ }^{4}$.

Interesujące jest to, jak koncerny farmaceutyczne obchodzą ustawowe obostrzenia dotyczące reklam leków. Spot suplementu diety nie może wprowadzać w błąd ani sugerować, że produkt leczy. Producenci omijają ten przepis na różne sposoby, na przykład poprzez nieprecyzyjne określenia - zamiast słowa „leczy” pojawiają się określenia: „pomaga”, „dba”, „działa korzystnie”, „wspiera”, „przyczynia się do prawidłowego funkcjonowania”.

\section{Badanie}

Metodologia badawcza, która pozwoliła na analizę materiału, jest tożsama z tą, która została użyta przez Mariusza Wszołka w badaniach nad dyferencjami rynkowymi. Jednak w odróżnieniu od nich poddano analizie nie reklamy prasowe, lecz telewizyjne. Jeśli chodzi o inne aspekty metodologiczne, przyjęto za Wszołkiem, że:

1 GUS: najważniejsze dla Polaków jest zdrowie i rodzina, http://www.pap.pl/aktualnosci/ news,435819,gus-najwazniejsze-dla-polakow-jest-zdrowie-i-rodzina.html (dostęp: 25 sierpnia 2017).

2 Na leki wydajemy coraz więcej. Raport DNB Bank Polska i Deloitte „Sektor farmaceutyczny i med-tech", http://www2.deloitte.com/pl/pl/pages/press-releases/articles/IP-dnb-sektor-farmaceutyczny. html (dostęp: 21 października 2017).

3 Wydatki na reklamęleków rosną na potęę, http://wyborcza.biz/biznes/1,147743,19447593,wydatkina-reklame-lekow-rosna-na-potege.html (dostęp: 21 sierpnia 2017).

4 Sektor farmaceutyczny zwiększył nakłady reklamowe, liderem Aflofarm, http://www.wirtualnemedia.pl/artykul/branza-farmaceutyczna-wydatki-reklamowe-w-2017-roku-liderem-aflofarm (dostęp: 24 września 2017). 
- Jako metodologię badawczą przyjmuje się analizę dyskursu z wykorzystaniem materiału wizualnego jako materiału badawczego.

- W analizie nie stosuje się wyróżnienia wybranych zmiennych (na przykład tekst użyty w reklamie), ale traktuje się analizowane oferty komunikacyjne jako jednorodny rekord.

- W ramach sformalizowanych metod analizy materiałów wizualnych stosuje się między innymi analizę treści, analizę treści jawnej i ukrytej, które dla zweryfikowania postawionych problemów badawczych nie są wystarczającymi narzędziami poznawczymi, chociażby ze względu na swój ilościowy charakter.

- Analiza dyskursu jednoznacznie wyklucza obiektywizm prowadzenia procesu analitycznego $\mathrm{z}$ uwagi na postawienie $\mathrm{w}$ centrum oceny analizowanego zjawiska badacza i jego kompetencji poznawczych $^{5}$.

Ze względu na dużą liczbę reklam leków i suplementów diety obecnych na rynku telewizyjnym zdecydowano się na analizę materiału egzemplifikacyjnego, za który posłużyły reklamy leków i suplementów diety zamieszczone na oficjalnym kanale firmy farmaceutycznej USP Zdrowie na portalu YouTube ${ }^{6}$. Na dzień zakończenia analizy, czyli 3 maja 2018 roku, na kanale znajdowało się 77 reklam.

Poniżej opisano strategie, które zostały wyodrębnione w toku analizy materiału badawczego. Zaobserwowano, że powtarzają się one najczęściej w danym sektorze, ale $\mathrm{z}$ pewnością nie są jedynymi możliwymi do wyodrębnienia. Z uwagi na formę analizowanych reklam, czyli spoty telewizyjne, często kilka strategii występuje w obrębie jednej reklamy.

\section{Wzbudzenie zaufania}

Jeśli chodzi o sektor farmaceutyczny, bardzo często można spotkać się z reklamami produktów, w których zaufanie komunikowane jest poprzez odwołanie się do autorytetu lub operowanie danymi procentowymi.

Symbolem autorytetu w reklamach leków i suplementów diety jest najczęściej postać lekarza lub farmaceuty. Nawiązuje to do jednej z klasycznych reguł wpływu społecznego opracowanych przez Roberta Cialdiniego ${ }^{7}$ i wiąże się ze skłonnością ludzi do ulegania innym osobom posiadającym wysoką pozycję społeczną, budzącym zaufanie w danej kwestii, kompetencje w jakiejś dziedzinie lub dysponującym dowodami potwierdzającymi wysoki status. Taką rolę odgrywa najczęściej aktor ubrany w kitel, który ma sugerować odbiorcy, że jest autorytetem w swojej dziedzinie i dlatego można mu zaufać. Skojarzenie tej postaci z lekarzem - czyli zawodem zaufania publicznego - który ma nam pomóc i jak najlepiej doradzić, może skutkować tym, że wielu

5 M. Wszołek, Reklama. Perspektywa empiryczna, Wrocław-Kraków 2016, s. 123-125.

6 USP Zdrowie, https://www.youtube.com/user/uspzdrowiepolska (dostęp: 20 kwietnia 2018).

7 R. Cialdini, Reklama. Wywieranie wpływu na ludzi. Teoria i praktyka, przeł. B. Wojciszke, Gdańsk 1998.

Dziennikarstwo i Media 9, 2018

(C) for this edition by CNS 
odbiorców bezrefleksyjnie uwierzy, iż skoro w reklamie występuje lekarz polecający dany produkt, to nie może być to oszustwo, czy chociażby nadużycie.

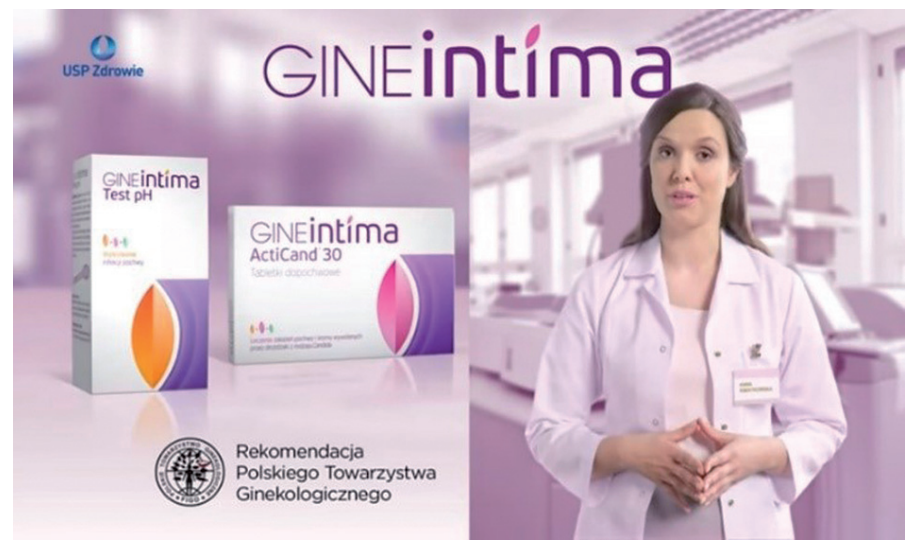

Ilustracja 1. Screen reklamy produktu Gineintima

Źródło: Kanał korporacyjny USP Zdrowie, https://www.youtube.com/watch?v=zInSnddmA3E (dostęp: 18 grudnia 2017).

Oprócz mocnych elementów wizualnych, jak wspomniany kitel, w reklamach farmaceutyków można spotkać także treści językowe, które mają wzbudzić zaufanie odbiorcy do reklamowanego produktu. Może to być na przykład rekomendacja Polskiego Towarzystwa Ginekologicznego - dużej, prawdopodobnie państwowej, a przez to niezależnej, instytucji (il. 1).

Na zaufanie może wpływać także używanie w komunikacie danych procentowych bądź sformułowań językowych, które sugerują, że produkt jest używany czy polecany nie tylko przez autorytety, ale także przez „Zwykłych ludzi”.

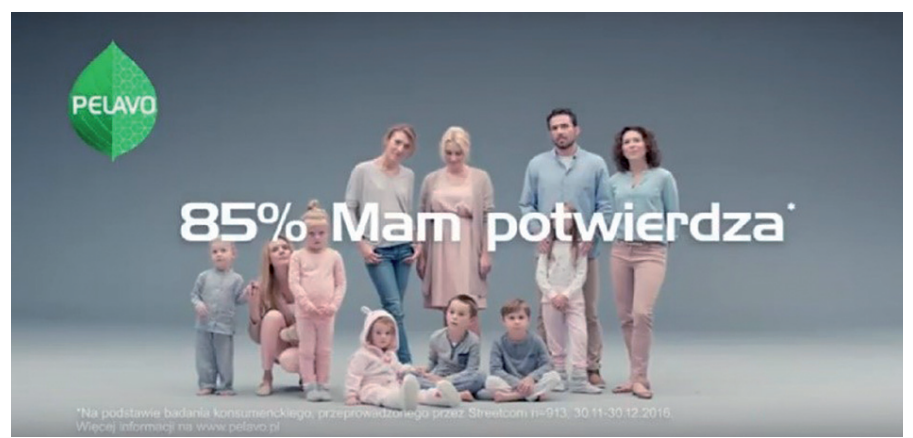

Ilustracja 2. Screen reklamy produktu Pelavo

Źródło: Kanał korporacyjny USP Zdrowie, https://www.youtube.com/watch?v=hrwQnC0sD38\&list=UUTt_ ECdVuxf5jRzNXPyl32g\&index=8 (dostęp: 18 grudnia 2017). 
Stwierdzenie „85\% Mam potwierdza” (bez wczytywania się w wyjaśnienie) daje konkretny, językowy sygnał, że wiele osób stosuje dany produkt, dlatego (w domyśle) jest on skuteczny i warto go stosować. Zabieg ten nawiązuje do innej psychologicznej reguły wpływu - społecznego dowodu słuszności. Opiera się na uniwersalnym mechanizmie konformizmu, który — w dużym skrócie — mówi o tym, iż jesteśmy bardziej skłonni coś polubić lub wypróbować, wiedząc, że zrobiło to już wiele osób. Jeżeli inni ludzie postępują w dany sposób, oznacza to, że ten sposób jest właściwy i ja również będę postępował w ten sam sposób.

Pomocne we wzbudzeniu zaufania do produktu jest również zakomunikowanie jego wyjątkowości poprzez pokazanie go jako „numeru 1” czy „lidera” w grupie podobnie działających specyfików.

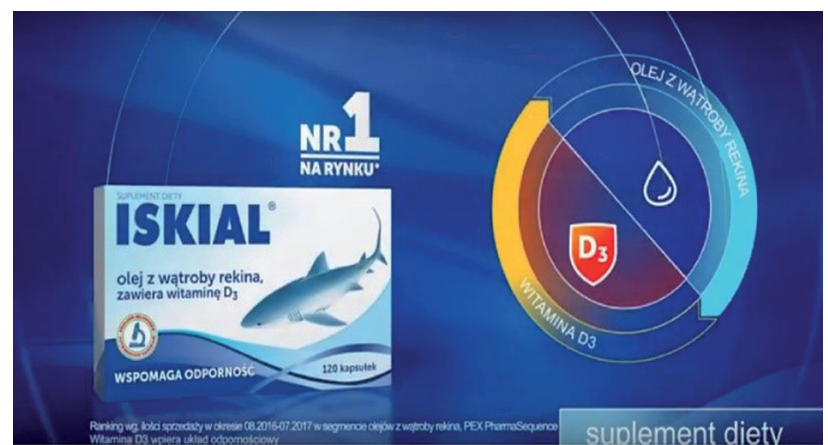

Ilustracja 3. Screen reklamy produktu Iskial

Źródło: Kanał korporacyjny USP Zdrowie, https://www.youtube.com/watch?v=uSMC3KVbaN4\&index=9\&list=UUTt_ECdVuxf5jRzNXPyl32g (dostęp: 18 grudnia 2017).

Ten z pozoru prosty zabieg retoryczny jest bardzo często stosowany w reklamie, w bardzo wielu segmentach rynkowych. Można go uznać za przykład argumentum ad populum, czyli argumentacji odwołującej się do poglądu większości, tłumu. Skoro jest to lider bądź numer 1, to musi to być prawda, bo przecież zbiorowość nie może się mylić.

\section{Skuteczność/precyzja}

Strategia odwołania się do skuteczności i/lub precyzji działania reklamowanego środka jest w sektorze farmaceutycznym najczęściej związana z tym, że dany specyfik w odpowiedni sposób rozwiązuje problemy, działa szybko i długo oraz oddziałuje dokładnie na te obszary organizmu, które powodują dyskomfort. Owa skuteczność czy precyzja jest potwierdzona tym, że reklamowany produkt powoduje przejście od stanu dyskomfortu i choroby do stanu zdrowia i radości. Nie chodzi jednak jedynie 
o pokonanie samego bólu, lecz właśnie o szybkość i długość działania przeciwbólowego. Dlatego w warstwie językowej często używane są takie sformułowania, jak: „działa już po”, „o natychmiastowym działaniu”, „szybko trafia w źródło bólu”, „działa aż do”, „o przedłużonym działaniu”, „działa dłużej niż”. Ważnym aspektem jest tutaj nie tylko samo pokonanie bólu, lecz także to, aby odbyło się ono jak najszybciej i trwało jak najdłużej. Oczywiste jest bowiem, że odbiorca chce, by jak najszybciej minął stan, który uniemożliwia mu funkcjonowanie, i by jak najdłużej trwał u niego stan bez bólu. Skuteczność jest więc tutaj utożsamiana z czymś więcej niż tylko rozwiązanie problemu.

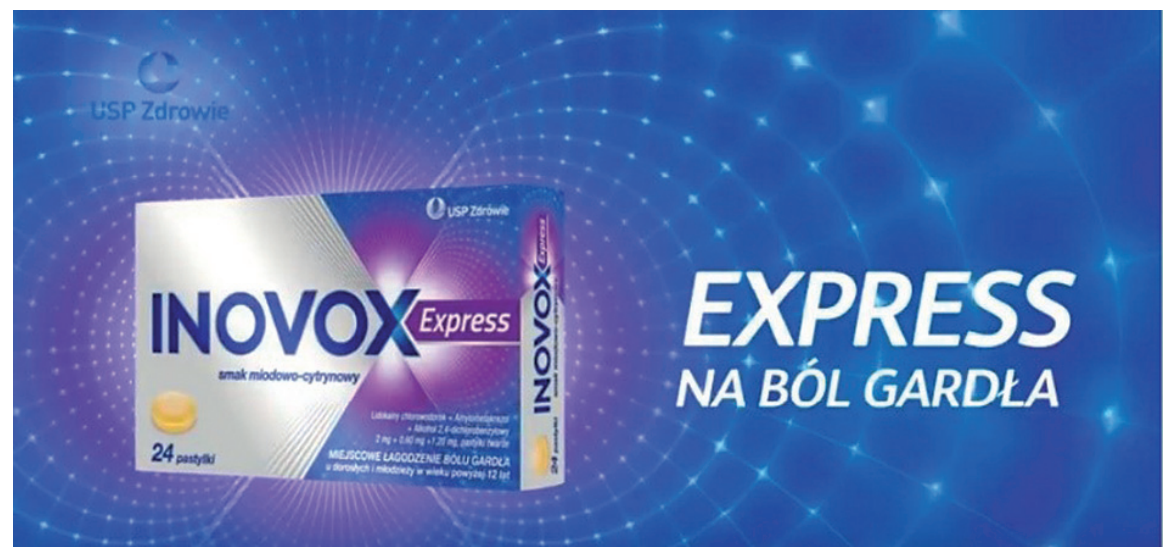

Ilustracja 4. Screen reklamy produktu Inovox Express

Źródło: Kanał korporacyjny USP Zdrowie, https://www.youtube.com/watch?v=K_AnuyVRzkA\&index=11\&list=UUTt_ECdVuxf5jRzNXPyl32g (dostęp: 15 grudnia 2017).

Aby dosadniej zakomunikować skuteczność i precyzję, w reklamach leków i suplementów diety często obrazuje się mechanizm ich działania. Część reklamy jest zarezerwowana na pokazanie profesjonalnej, trójwymiarowej wizualizacji, która prezentuje działanie leku w organizmie człowieka, deklarując przy okazji jego szybkość i skuteczność. W towarzyszących wizualizacjom zwrotach językowych mowa jest o źródle bólu - prezentowany specyfik szybko i celnie w nie trafia, lokalizuje je. Wizualizację zazwyczaj poprzedza scena pokazująca zastosowanie środka przez bohatera reklamy, na przykład połknięcie tabletki czy zastosowanie maści. Czas od zastosowania do aktywnego działania, czyli w domyśle: od pomocy do wyleczenia, to zwykle kilka sekund. Zwrot „Możesz użyć maksymalnej siły Gripexu... i zwalczasz wszystkie te objawy maksymalnymi dawkami składników" w połączeniu z elementami wizualnymi jest jasnym komunikatem, że jest to silny i skuteczny środek. Dodatkowo krótki czas trwania spotu może wzmagać w odbiorcy przekonanie, że lek jest naprawdę skuteczny, a przede wszystkim szybki, ponieważ w ciągu kilkunastu sekund zostało zaprezentowane jego całościowe działanie. 


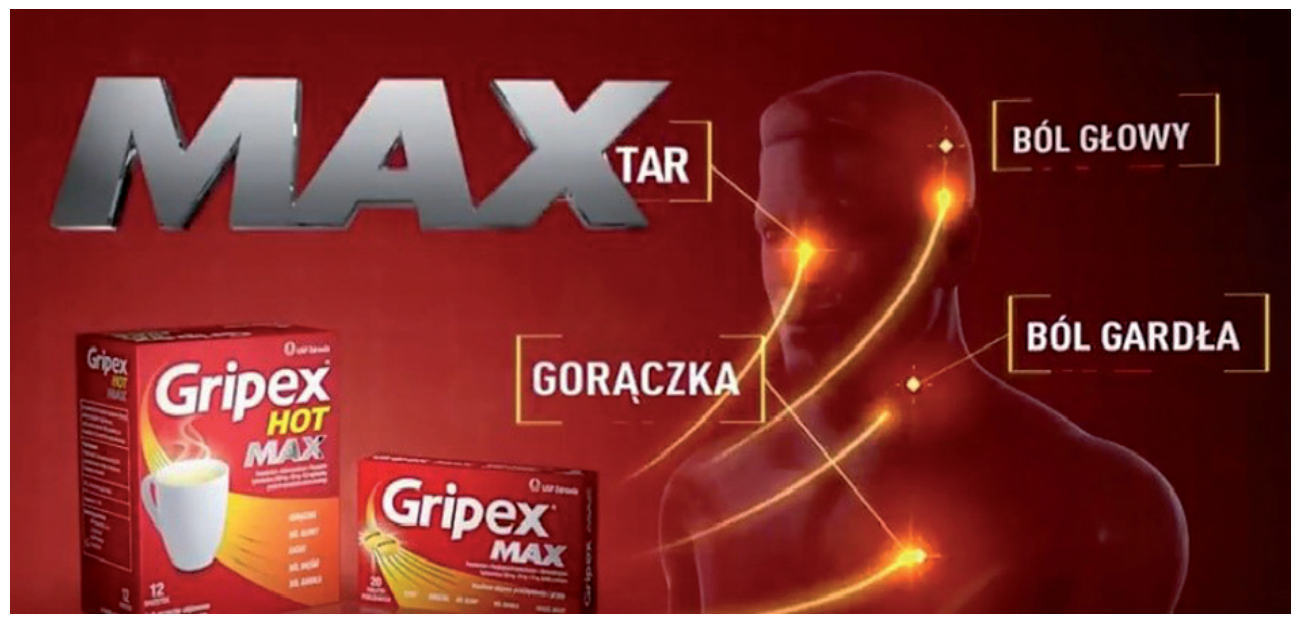

Ilustracja 5. Screen reklamy produktu Gripex Max

Źródło: Kanał korporacyjny USP Zdrowie, https:/www.youtube.com/watch?v=ifOFgGGAkGM\&index=7\&list=UUTt_ECdVuxf5jRzNXPyl32g (dostęp: 15 grudnia 2017).

Skuteczność i precyzję działania często podkreśla się, komunikując innowacyjność danego specyfiku. Fachowa, często obco brzmiąca, nazwa technologii ma na celu zwrócenie uwagi na unikalność, a tym samym siłę i skuteczność produktu, co sugeruje zwrot użyty w reklamie „...które dzięki technologii MURE skutecznie docierają do jelit, aby uzupełnić osłabioną florę".

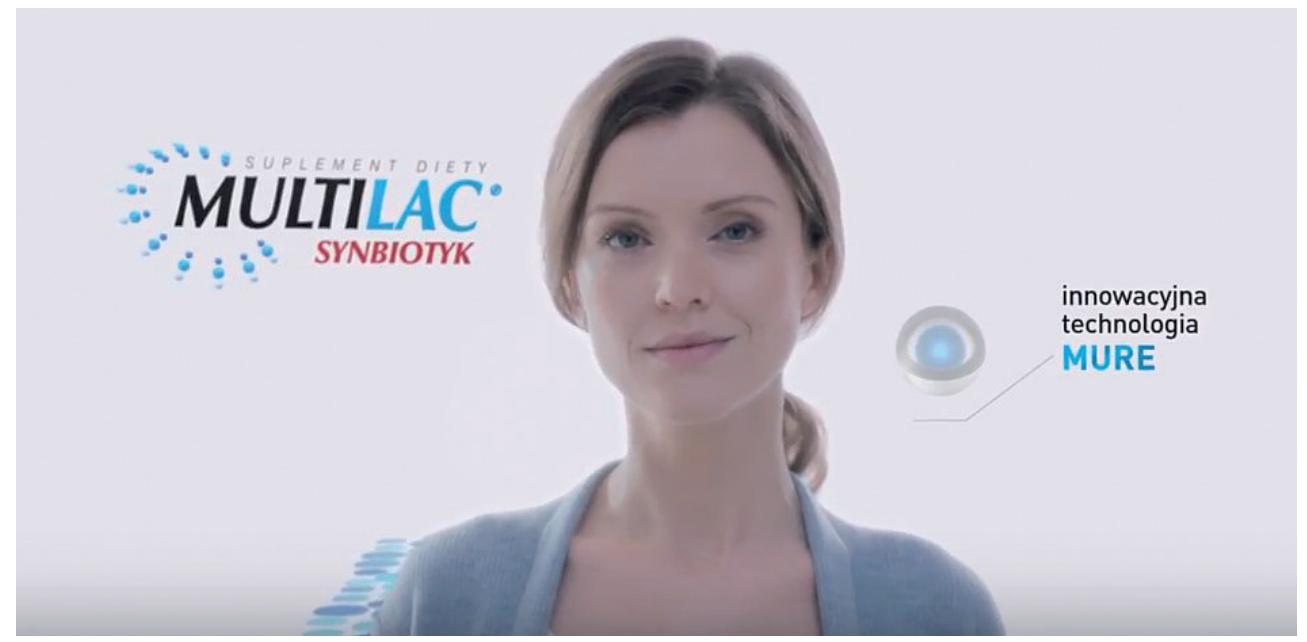

Ilustracja 6. Screen reklamy produktu Multilac

Źródło: Kanał korporacyjny USP Zdrowie, https://www.youtube.com/watch?v=TFAf8PwebpQ (dostęp: 13 grudnia 2017).

Dziennikarstwo i Media 9, 2018

(C) for this edition by CNS 


\section{Szczęście}

Strategia komunikacyjna odwołująca się do szczęścia zazwyczaj polega na pokazaniu, że użycie danego specyfiku prowadzi do szczęścia, choć oczywiście może ono być wyrażane na różne sposoby.

Często reklamy farmaceutyków wykorzystują motyw szczęścia rodzinnego. Taki sposób komunikacji bazuje na bardzo ważnej, widocznej w badaniach społecznych wartości, czyli rodzinie. Reklama pokazuje sceny z życia rodziny, na przykład jedna scena ze smutną rodziną, kiedy przyczyną smutku jest dolegliwość jednego z jej członków, i druga ze szczęśliwą, bawiącą się rodziną, czyli już po pokonaniu dolegliwości dzięki zastosowaniu reklamowanego preparatu.

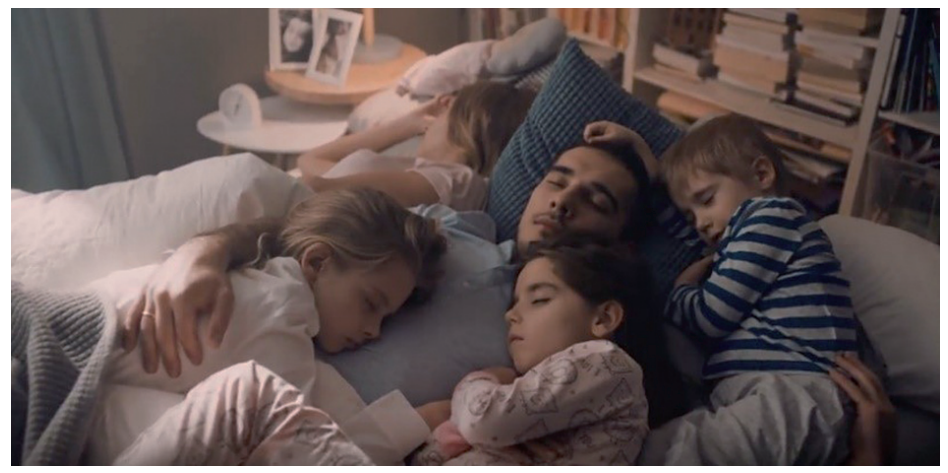

Ilustracja 7. Screen reklamy produktu Apap

Źródło: Kanał korporacyjny USP Zdrowie, https://www.youtube.com/watch?v=nJSWHTnAXX8 (dostęp: 15 grudnia 2017).

Fragment spotu: „Jestem Maciek. Jestem ojcem Oli, Julii i Franka. Ogólnie jest super, jest dużo śmiechu, zabawy. Ale czasami po prostu wszystko mnie boli. Na szczęście jest APAP” pokazuje, że to dzięki reklamowanemu specyfikowi ojciec nie musi przejmować się bólem i może zapewnić dzieciom szczęście - może się z nimi bawić. Z jednej strony szczęściem jest tutaj czas aktywnie spędzany z dziećmi, ale $\mathrm{z}$ drugiej, co podkreślono, także to, że istnieje APAP, który to umożliwia.

\section{Dobry doradca}

Dobry doradca to strategia, która tak jak większość wcześniej opisanych rozpoczyna się od pokazania problemów jednego z bohaterów. Może to być ból, problemy gastryczne, kłopoty z koncentracją i wiele innych. Bohater opowiada o swoich dolegliwościach, złym samopoczuciu. Źle wygląda, jest w ponurym nastroju. Po chwili okazuje się, że sposobem na rozwiązanie jego problemów była rada, jakiej udzielił mu 
dobry doradca. Oczywiście odnosiła się ona do preparatu, który zdaniem doradcy na pewno szybko i skutecznie zwalczy dolegliwości bohatera.

Strategia ta może być pokazana na dwa sposoby. Pierwszy to narracja bohatera, który opowiada o tym, że miał pewien problem zdrowotny — był on uciążliwy, bohater nie wiedział, co z nim zrobić. Wtedy ktoś znajomy (przyjaciel lub członek rodziny) polecił mu dany produkt, który okazał się skuteczny i pomógł bohaterowi.

Drugi sposób prezentacji tej strategii w reklamie to sytuacja, w której widzimy co najmniej dwójkę bohaterów. Pierwszym z nich jest osoba, która ma problem, której coś dolega; drugi bohater to osoba, która słysząc o problemach lub je widząc, okazuje się dobrym doradcą - wie, co może pomóc, i zazwyczaj ma pod ręką właściwy preparat, dzięki czemu osoba z dolegliwościami może od razu z niego skorzystać. Doradca opowiada o zaletach produktu, często wspomina, że pomógł on także jemu. Ponieważ bohater ufa doradcy, od razu decyduje się skorzystać z preparatu. Jego problemy mijają, a on sam staje się radosny. Przy takiej strategii nie mamy do czynienia z głosem bezosobowego narratora, tylko z dialogiem pomiędzy bohaterami reklamy, na przykład: „Motyle? W brzuchu to ja czuję zaparcie”, „Nie męcz się. Weź na noc Xennę Extra Comfort, która niczym motyle pobudzi Twoje jelita do działania”.
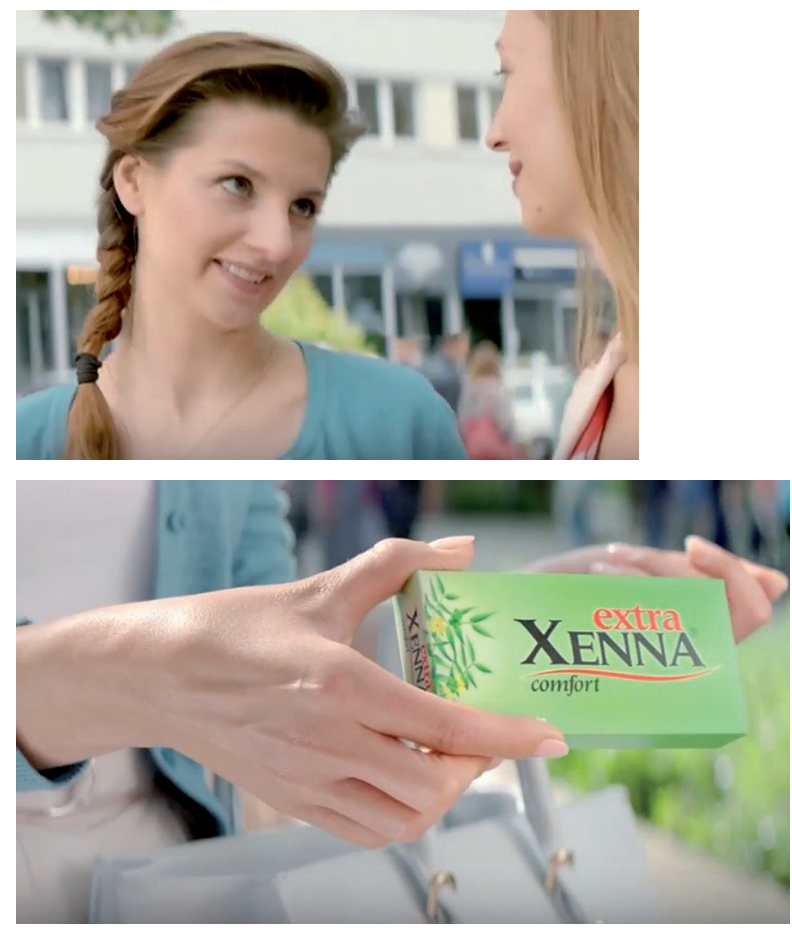

Ilustracja 8. Screen reklamy produktu Xenna extra

Źródło: Kanał korporacyjny USP Zdrowie, https://www.youtube.com/watch?v=-cKZrHy3Rck (dostęp: 15 grudnia 2017).

Dziennikarstwo i Media 9, 2018

(C) for this edition by CNS 


\section{Podsumowanie}

Przedstawione powyżej strategie komunikacji to oczywiście nie wszystkie, które są wykorzystywane w sektorze farmaceutycznym. Wydaje się jednak, że można je uznać za wykorzystywane najczęściej - mogą więc one obrazować techniki, jakich używają producenci reklam w swojej komunikacji. Przedstawione strategie koncentrują się przede wszystkim na ukazaniu dyskomfortu i zwalczaniu dolegliwości oraz na ważnym elemencie happy endu. Bazują na prostych scenariuszach, schematach i sloganach, które cechuje duża dosłowność i mocne eksponowanie produktu. Ważnym elementem jest nacechowanie emocjonalne, na przykład pokazywanie szczęśliwej rodziny, smutnych dzieci czy postaci i motywów kojarzonych $\mathrm{z}$ autorytetami. $\mathrm{Na}$ perswazyjność przekazu może również wpływać akcentowanie szybkości, skuteczności i długości działania, które to elementy są zapewne bardzo ważne dla każdego potencjalnego odbiorcy danego produktu.

\section{The construction of communication in the advertising of medicines and dietary supplements}

Summary

The article is focused on the issue of communication constructs that are most often used in advertising of medicines and dietary supplements. Medical companies spend more and more money on advertising their products, which causes an increase in sales of pharmaceuticals and para-pharmaceuticals. A variety of manipulative techniques and social influence are used in advertising. Increasingly we can see repetitive communication strategies and language constructs, which are based on such ads. The pharmaceutical sector is one of the top advertisers in terms of spending on promotion - it invariably remains in the second position. More money is spent only by the sector of food and beverages.

The most often used strategies focus primarily on showing discomfort and overcoming problems as an important part of a happy end. Based on simple scenarios, patterns, and slogans, which are characterized by uncomplitated message and strong visibility of the product. Strong emotional components are an important element, for example showing a happy family or sad children. What persuasive communication is like can also be affected through emphasis on speed, efficiency and length of action. This element is probably very important for each potential recipient of the product.

Dziennikarstwo i Media 9, 2018

(C) for this edition by CNS 